\title{
PENGARUH GAYA HIDUP KONSUMTIF DAN PROMOSI PENJUALAN TERHADAP PEMBELIAN IMPULSIF MAKANAN KEKINIAN MAHASISWA URBAN SURABAYA
}

\author{
Tamara Virsa Putri \\ Universitas Negeri Surabaya \\ tamaraputri16080574096@mhs.unesa.ac.id \\ Sri Setyo Iriani \\ Universitas Negeri Surabaya \\ srisetyo@unesa.ac.id
}

Abstract

\begin{abstract}
Surabaya is the capital of the Indonesian province of east java and the second most populous city plus metropolitan area in Indonesia after Jakarta with 3.158 .943 citizens recorded in the 2019 census. Surabaya citizen does not only consist of indigenous people who settled in Surabaya but also people outside the city who urbanized to Surabaya. The city is highly urbanized with industries centralized in the city, one sector that is urbanized to Surabaya aside the labor sector is from the education sector. Surabaya has a variety of reputable state and private campuses that serve as a destination for students from various regions to pursue their education. Urbanization conducted by urban students makes their lifestyle more consumptive with the facilities and easy access in Surabaya. One of them is the easy access to the famous food in every corner of the city with various sales promotions (discounts and cashback) offered by marketers to stimulate purchases by urban students. The changes in lifestyle and the various sales promotion stimulate urban students to make impulsive purchases. In this study, the population is 100 respondents. The result of the study revealed that a consumptive lifestyle has a significant effect on impulse buying so that urban students with a consumptive lifestyle tend to make more impulsive purchases. While the variable sales promotions don't have a significant effect on impulse buying which means that the promotions by the outlet do not affect the impulsive buying decision of urban students.
\end{abstract}

Keywords: consumptive lifestyles; impulsive buying; sales promotion.

\section{PENDAHULUAN}

Surabaya adalah kota dengan jumlah penduduk terbesar di Jawa Timur dan terbesar kedua setelah Jakarta di Indonesia. Sebagai ibu kota Jawa Timur dengan jumlah penduduk 3.158.943 jiwa (BPS, 2019). Sebagai ibukota Jawa Timur, arus urbanisasi merupakan hal yang tidak dapat dihindari. Urbanisasi yang terjadi di Surabaya disebabkan oleh banyaknya masyarakat yang mencari pekerjaan lebih layak di kota (Kompasiana.com, 2019).

Fenomena urbanisasi yang terjadi di masyarakat bukan hanya pada masyarakat yang sedang mencari pekerjaan tetapi juga pada mahasiswa yang menempuh pendidikan di Surabaya. Surabaya memiliki 109 Perguruan Tinggi baik itu swasta maupun Nasional dengan jumlah mahasiswa 262.880 pada tahun ajaran 2017/2018 dan 282.504 mahasiswa pada tahun ajaran 2018/2019. Jumlah mahasiswa yang meningkat 4\% dari tahun sebelumnya (Ristekdikti, 2019).

Salah satu penyumbang urbanisasi di Surabaya adalah mahasiswa, dalam KBBI urbanisasi mempunyai dua arti (1) perpindahan penduduk secara berduyun-duyun dari desa (kota kecil, daerah) ke kota besar (pusat pemerintahan) dan (2) perubahan tempat dari suasana (cara hidup dan sebagainya) desa ke suasana kota (KBBI, 2019). Berdasarkan pengertian di atas urbanisasi tidak hanya berdampak pada perpindahan tempat tetapi juga pada perubahan gaya hidup yang terjadi setelah mahasiswa berpindah dari kota asal ke Surabaya. Fasilitas yang disediakan oleh pemerintah kota Surabaya seperti pusat perbelanjaan modern, restoran cepat saji, kemudahan transportasi, kemudahan akses fasilitas keuangan mendukung perubahan gaya hidup mahasiswa urban yang dari asal kotanya tidak memiliki fasilitas sebanyak di Surabaya (Novitasani \& Handoyo 2014). 
Mahasiswa urban yang telah menetap di Surabaya mengalami beberapa perubahan gaya hidup, hal ini sejalan dengan penelitian yang dilakukan oleh Novitasani \& Handoyo (2014), mahasiswa urban mengalami perubahan gaya hidup meliputi cara berpakaian, kebiasaan nongkrong, dan gaya bahasa yang cenderung logat bahasa Surabaya. Dari keterangan di atas dilakukan pra survey kepada mahasiswa yang diisi oleh 59 orang mahasiswa yang menempuh pendidikan di Surabaya. Angket pra survey ini bertujuan untuk mengetahui bagaimana mahasiswa mengalokasikan uang yang mereka miliki untuk kebutuhan selama menempuh pendidikan di Surabaya.

Dari hasil pra survey yang telah dilakukan didapatkan hasil bahwa mahasiswa di Surabaya hanya mengalokasikan $14.78 \%$ dari uang saku yang mereka dapatkan untuk kebutuhan kuliah, padahal sebagai seorang mahasiswa kebutuhan utama yang harus dipenuhi adalah kebutuhan kuliah. Sedangkan untuk biaya membeli baju, jalan-jalan dan kebutuhan pribadi seperti skincare dan alat make up mencapai $35.54 \%$ jika digabungkan. Hal ini menunjukkan bahwa mahasiswa Surabaya lebih banyak membelanjakan uangnya untuk berbelanja dan nongkrong/jalan-jalan dibandingkan dengan untuk kebutuhan kuliah. Dari segi aktivitas sebagai salah satu pengukur gaya hidup, hasil dari pra penelitian menunjukkan bahwa mahasiswa di Surabaya memiliki kecenderungan untuk membelanjakan uangnya untuk berbelanja, dan dari pengeluaran jalan-jalan sebesar $14.26 \%$ yang artinya mahasiswa Surabaya banyak menghabiskan uang dan waktunya untuk kegiatan non akademik seperti nongkrong, bermain sosial media, mencari informasi tentang makanan maupun kegiatan yang sedang hits dilakukan.

Sebagai seorang mahasiswa kegiatan utama yang harusnya dilakukan adalah kuliah dan seharusnya pengeluaran yang dikeluarkan juga mengarah ke kebutuhan perkuliahan. Tetapi pada kenyataannya mahasiswa saat ini lebih banyak menghabiskan waktu dan uangnya untuk kepentingan lain seperti jalanjalan (Novitasani \& Handoyo, 2014). Kesenjangan ini berpengaruh pada motivasi dan nilai akademis yang rendah seperti penelitian yang dilakukan oleh Wahidah et al. (2018) yang membuktikan keterkaitan antara gaya hidup dengan prestasi kuliah, mahasiswa yang bergaya hidup konsumtif akan menurunkan motivasi kuliah dan mengakibatkan menurunnya indeks prestasi yang ditunjukkan dengan IPK yang cenderung rendah.

Gaya hidup didefinisikan sebagai pola di mana orang hidup dan menggunakan uang dan waktunya (Engel, Blackwell, \& Miniard, 2002 dalam Sumarwan, 2015:45). Mowen \& Minor (2001:283) mengemukakan bahwa metode yang paling sering digunakan untuk mengukur gaya hidup adalah skala AIO yaitu activities, interests dan opinions. Pertanyaan aktivitas meminta kepada konsumen untuk mengidikasikan apa yang mereka lakukan, apa yang mereka beli, dan bagaimana mereka menghabiskan waktu mereka. Pertanyaan minat memfokuskan pada preferensi dan prioritas konsumen. Sementara pertanyaan opini menyelidiki pandangan dan perasaan konsumen mengenai topik-topik peristiwa dunia, lokal, moral, ekonomi dan sosial.

Gaya hidup konsumtif adalah tindakan membeli barang-barang yang kurang atau tidak diperhitungkan sehingga sifatnya menjadi berlebihan (Anggarsari dalam Sumartono, 2002:45). Dari pra survey di atas dapat dilihat bahwa pengeluaran mahasiswa yang digunakan untuk makan merupakan pengeluaran yang paling besar yaitu $17.73 \%$, ditambah dengan pengeluaran jalan-jalan sebesar $14.26 \%$ yang di dalamnya juga termasuk makan. Dari data tersebut didapatkan hasil bahwa mahasiswa mengeluarkan banyak uang untuk membelanjakan makanan.

Hasil pra penelitian yang telah dilakukan ternyata mendukung hasil survey yang dilakukan oleh Slickdeals.net tahun 2018, studi dari 2000 konsumen di Amerika menunjukkan bahwa mereka melakukan tiga pembelian impulsif per minggu, sebanyak $\$ 450$ per bulan dan $\$ 5,400$ per tahun. Berdasarkan hasil survey tersebut juga didapatkan bahwa $71 \%$ responden mengatakan bahwa makanan adalah pembelian impulsif utama yang mereka lakukan (Slickdeals.net, 2018). Oleh karena itu penelitian ini akan berfokus pada gaya hidup konsumtif mahasiswa pada produk makanan.

Hasil survey (Slickdeals.net, 2018) menyebutkan 64\% dari responden mengatakan bahwa pembelian impulsif mereka dipengaruhi oleh deal dan diskon, $40 \%$ responden membeli karena kupon dari kotak masuk pos, $33 \%$ membeli setelah menerima kupon dari inbox email dan $21 \%$ lainnya membeli online. 
Survey di atas berbanding lurus dengan hasil penelitian yang dilakukan oleh Kwan (2016) menunjukkan bahwa promosi penjualan berpengaruh signifikan positif terhadap pembelian impulsif.

Generasi $\mathrm{Z}$ tak lepas dari penggunaan handphone dan internet, di mana segala jenis iklan dan promosi penjualan ditayangkan di berbagai platform internet. Tiga besar sosial media yang digunakan oleh generasi $\mathrm{Z}$ yaitu $89 \%$ youtube, $77 \%$ facebook dan $75 \%$ instagram. Banyak brand bekerja sama dengan influencer, paid post dan iklan diantara video yang ditayangkan di youtube (Voguebusiness.com, 2020). Salah satunya adalah iklan OVO yang dapat dijumpai di youtube maupun instagram dengan menawarkan promosi penjualan seperti cashback.

Menurut Kotler \& Keller (2009:219), promosi penjualan yang merupakan kumpulan alat-alat insentif yang beragam, sebagian besar berjangka pendek, dirancang untuk mendorong pembelian suatu produk atau jasa tertentu secara cepat dan atau lebih besar oleh konsumen. Sedangkan menurut Tjiptono \& Chandra (2012:229), promosi penjualan adalah bentuk persuasi langsung melalui penggunaan berbagai insentif yang dapat diatur untuk merangsang pembelian produk dengan segera dan meningkatkan jumlah barang yang dibeli pelanggan. Dari pengertian di atas dapat diartikan bahwa promosi penjualan adalah alat untuk menstimuli konsumen agar membeli produk/jasa yang ditawarkan. Banyaknya promosi penjualan dan media promosi yang mudah diakses oleh masyarakat meningkatkaan pembelian tidak terencana karena tergiur oleh promosi-promosi yang telah dilakukan pelaku bisnis.

Penelitian yang dilakukan oleh Nurmasarie (2013) menyatakan bahwa, promosi penjualan mempengaruhi keputusan belanja tidak terencana. Keputusan belanja tidak terencana atau biasa disebut pembelian impulsif menurut Mowen \& Minor (2001:10), pembelian impulsif didefinisikan sebagai tindakan membeli yang sebelumnya tidak dilakukan secara sadar sebagai akibat dari pertimbangan atau niat pembelian yang dibentuk sebelum memasuki toko. Menurut Utami (2018:56), pembelian impulsif didefinisikan sebagai suatu desakan hati yang tiba-tiba dengan penuh kekuatan, bertahan dan tidak direncanakan, untuk membeli secara langsung, tanpa banyak memperhatikan akibatnya. Jadi, pembelian impulsif adalah tindakan membeli suatu barang/jasa yang tidak direncanakan dan cenderung bersifat emosional.

Penelitian Kwan (2016) membuktikan sales promotion mempunyai pengaruh yang positif dan signifikan terhadap impulse buying. Rebat dan penawaran diskon serta program loyalitas berpengaruh signifikan terhadap impulse buying, sedangkan kupon, paket bonus dan kontes tidak signifikan (Nagadeepa et al. 2015). Amara \& Kchaou (2014) mengatakan bahwa perceived value dan promosi berpengaruh terhadap pembelian impulsif. Sedangkan dalam penelitian, Waani \& Tumbuan (2015) di dapatkan hasil bahwa diskon harga tidak berpengaruh terhadap pembelian impulsif.

Tujuan dari penelitian ini adalah untuk menganalisis pengaruh gaya hidup konsumtif dan promosi penjualan mahasiswa urban terhadap terjadinya pembelian impulsif pada outlet makanan kekinian di Surabaya.

\section{KAJIAN PUSTAKA DAN PENGEMBANGAN HIPOTESIS}

\section{Gaya Hidup Konsumtif}

Gaya hidup adalah pola hidup seseorang di dunia terungkap pada aktivitas, minat dan opininya (Kotler \& Keller, 2009:175) Sedangkan menurut Mowen \& Minor (2001:28), gaya hidup adalah menunjukkan bagaimana orang hidup, bagaimana membelanjakan uangnya, dan bagaimana mengalokasikan waktu. Jadi, gaya hidup adalah cara seseorang mengalokasikan waktu, uang dan tenaganya menurut aktivitas, minat dan opininya.

Perilaku konsumtif adalah tindakan membeli barang-barang yang kurang atau tidak diperhitungkan sehingga sifatnya menjadi berlebihan (Anggarsari dalam Sumartono, 2002:45). Menurut Sumartono (2002:117), perilaku konsumtif adalah suatu tindakan menggunakan suatu produk secara tidak tuntas, di mana belum habis produk yang dipakai, seseorang telah menggunakan produk lain dengan fungsi 
Tamara Virsa Putri \& Sri Setyo Iriani. Pengaruh Gaya Hidup Konsumtif dan Promosi Penjualan Terhadap Pembelian Impulsif Makanan Kekinian Mahasiswa Urban Surabaya

yang sama. Jadi, perilaku konsumtif adalah suatu tindakan yang dilakukan individu secara berlebihan dalam mengkonsumsi suatu produk.

Indikator yang digunakan pada penelitian ini adalah (1) Membeli produk demi menjaga penampilan dan gengsi (2) Membeli produk karena iming-iming hadiah (3) Membeli produk karena kemasannya menarik (4) Mencoba lebih dari dua produk sejenis (merek beda) (Pramudi, 2015; Pradana, 2013).

\section{Promosi Penjualan}

Menurut Tjiptono \& Chandra (2012:367), promosi penjualan adalah segala bentuk penawaran atau insentif jangka pendek yang ditUjukan bagi pembeli, pengecer atau pedagang grosir dan dirancang untuk memperoleh respon spesifik dan segera. Lupiyoadi (2013:180) mengemukakan promosi penjualan adalah semua kegiatan yang dimaksudkan untuk meningkatkan arus barang atau jasa dari produsen sampai pada penjualan kahirnya. Menurut Kotler \& Keller (2009:219), promosi penjualan yang merupakan kumpulan alat-alat insentif yang beragam, sebagian besar berjangka pendek, dirancang untuk mendorong pembelian suatu produk atau jasa tertentu secara cepat dan atau lebih besar oleh konsumen. Jadi, promosi penjualan adalah kegiatan atau usaha yang dilakukan pemasar untuk mendorong pembelian barang atau jasa secara cepat.

Berbagai jenis promosi penjualan menurut Tjiptono \& Chandra (2012:369) adalah kupon, deals, premium (diskon), kontes, undian, produk sampel, trading stamps, point-of-purchase- display, dan potongan rabat. Indikator yang digunakan pada penelitian ini adalah (1) Frekuensi diskon (2) Besaran diskon (3) Frekuensi cashback (4) Besaran cashback (5) I like to buy under promotion (Amara \& Kchaou, 2014 dan Wahyudi, 2017).

\section{Pembelian Impulsif}

Menurut Rook dan Gardner (1993) (dalam Sari, 2014) Pembelian impulsif di definisikan sebagai pembelian yang spontan yang ditandai dengan pengambilan keputusan yang relatif cepat. Menurut Utami (2018:56) pembelian impulsif didefinisikan sebagai suatu desakan hati yang tiba-tiba dengan penuh kekuatan, bertahan dan tidak direncanakan, untuk membeli secara langsung, tanpa banyak memperhatikan akibatnya.

Loudon \& Bitta (dalam Wahyudi, 2017) menyebutkan empat tipe pembelian impulsif (impulse buying) sebagai berikut: (1) Pure impulse adalah sebuah pembelian yang berlawanan dengan tipe pembelian normal yangmana konsumen benar benar membeli suatu barang tanpa berpikir atau merencanakannya sebelumnya. (2) Suggestion impulse adalah ketika seorang pembeli tidak mempunyai pengetahuan sebelumnya tentang sebuah produk, mereka melihatnya untuk pertama kali, dan merasakan kebutuhan akan produk tersebut. (3) Reminder impulse adalah ketika seorang pembeli melihat sebuah produk dan teringat bahwa persediaan produk tersebut di rumah sudah berkurang, atau mengingat sebuah iklan atau informasi lain tentang sebuah produk dan keputusan pembelian terdahulu. (4) Planned impulse, seorang pembeli memasuki toko dengan ekspektasi dan tujuan untuk melakukan pembelian berdasarkan adanya harga spesial, kupon, dan sejenisnya.

Beatty dan Ferrel (dalam Wahyudi, 2017) menyebutkan bahwa yang menjadi skala pengukuran untuk mengukur skala impulse buying ke dalam tujuh dimensi, yaitu: desakan untuk berbelanja (urge to purchase), emosi positif (positive affects), melihat-lihat toko (in-store browsing), kesenangan berbelanja (shopping enjoyment), ketersediaan waktu (time available), ketersediaan uang (money available), dan kecenderungan pembelian impulsif (impulse buying tendency).

Indikator pembelian impulsif adalah (1) Membeli dipengaruhi keadaan emosional (2) Membeli tanpa memedulikan akibat (3) Ketika melihat suatu produk, ada keinginan untuk membeli produk tersebut saat itu juga (Amara \& Kchaou, 2014 dan Sari, 2014).

\section{Hubungan antar Variabel}

(Sumarwan, 2015:45) menyebutkan bahwa pola di mana orang hidup dan menggunakan uang dan waktunya mempengaruhi bagaimana seseorang tersebut mengambil suatu keputusan. Keputusan dapat 
bersifat rasional maupun irrasional, salah satu keputusan tidak rasional atau irrasional adalah pembelian impulsif. Sumartono (2002:117), perilaku konsumtif adalah suatu tindakan menggunakan suatu produk secara tidak tuntas, di mana belum habis produk yang dipakai, seseorang telah menggunakan produk lain dengan fungsi yang sama. Seseorang dengan gaya hidup ini akan melakukan pembelian yang tidak terencana ketika melihat suatu produk yang menarik untuknya meskipun dia tidak berniat untuk membeli produk tersebut pada awalnya dan tidak membutuhkan atau belum membutuhkan produk tersebut hal ini yang akhirnya mendorong pembelian impulsif.

Hasil penelitian sebelumnya yang dilakukan oleh Nato (2018) menyatakan bahwa Gaya Hidup berpengaruh terhadap kecenderungan Impulse buying. Hasil penelitian lainnya yang dilakukan oleh Ahmed et al. (2015) juga menyatakan bahwa Gaya Hidup berpengaruh terhadap kecenderungan Impulse buying.

H1: Gaya hidup konsumtif berpengaruh terhadap pembelian impulsif produk makanan kekinian pada mahasiswa urban Surabaya.

Promosi penjualan yang adalah kegiatan atau usaha yang dilakukan pemasar untuk mendorong pembelian barang atau jasa oleh konsumen atau pelanggan secara cepat. Dengan adanya promosi penjualan diharapkan konsumen memutuskan untuk membeli suatu produk bahkan ketika konsumen tersebut tidak membutuhkan produk tersebut. Berbagai macam promosi penjualan dilakukan oleh pemilik outlet makanan kekinian seperti melakukan diskon serta bekerja sama dengan beberapa $e$ money atau $e$-wallet sehingga pengguna $e$-money atau $e$-wallet tersebut dapat mendapatkan keuntungan ketika membeli di outlet tersebut. Kegiatan berbagai promosi penjualan tersebut menstimuli atau mendorong konsumen untuk melakukan pembelian bahkan ketika konsumen tersebut tidak berencana untuk membeli produk tersebut sehingga mendorong pembelian impulsif.

Stimulus dari promosi penjualan dapat menciptakan suatu keputusan pembelian irrasional seperti hasil penelitian sebelumnya yang dilakukan Nagadeepa et al. (2015) menyatakan bahwa jenis promosi penjualan rabat dan diskon berpengaruh signifikan terhadap impulse buying. Hasil penelitian lainnya yang dilakukan oleh Xu \& Huang (2014) menyatakan bahwa diskon dan bonus paket berpengaruh signifikan terhadap promosi penjualan. Kwan (2016) menyatakan Sales promotion mempunyai pengaruh yang positif dan signifikan terhadap impulse buying.

H2: Promosi penjualan berpengaruh terhadap pembelian impulsif produk makanan kekinian pada mahasiswa urban Surabaya.

\section{METODE PENELITIAN}

Jenis pendekatan yang digunakan dalam penelitian ini yaitu pendekatan kausal yang berguna dalam mencari bukti sebuah hubungan sebab dan akibat yang dapat menimbulkan pengaruh antar variabel. Selain itu, jenis rancangan yang digunakan yaitu rancangan konklusif di mana rancangan ini bertujuan untuk mengevaluasi hubungan antara data yang didapatkan serta analisis menggunakan secara kuantitatif (Malhotra \& Birks, 2007:90).

Rancangan penelitian digunakan untuk mengetahui pengaruh antara variabel, apakah terdapat pengaruh variabel bebas (eksogen) yaitu gaya hidup konsumtif (X1) dan promosi penjualan (X2) terhadap variabel terikatnya (endogen) yaitu Pembelian Impulsif (Y).

Data primer yang digunakan di penelitian berasal dari hasil angket jawaban responden tentang gaya hidup konsumtif, promosi penjualan, dan pembelian impulsif. Data primer diperoleh langsung dari responden yang menjadi subjek penelitian di mana data dihasilkan dari instrument angket yang didistribusikan kepada sampel yang telah ditentukan. Pengolahan data dalam penelitian ini menggunakan Regresi Linear Berganda dan menggunakan program SPSS. 
Tamara Virsa Putri \& Sri Setyo Iriani. Pengaruh Gaya Hidup Konsumtif dan Promosi Penjualan Terhadap Pembelian Impulsif Makanan Kekinian Mahasiswa Urban Surabaya

Populasi dalam penelitian ini adalah mahasiswa urban Surabaya yang menempuh pendidikan di universitas di Surabaya yang mempunyai beberapa karakteristik yakni: (1) Responden merupakan Mahasiswa urban yaitu mahasiswa yang berasal dari luar kota Surabaya yang menempuh pendidikan di salah satu perguruan tinggi di Surabaya. (2) Responden minimal telah tinggal di Surabaya selama 1 tahun. (3) Responden pernah melakukan pembelian impulsif terhadap makanan kekinian (pembelian yang tidak direncanakan) minimal sekali dalam tiga bulan terakhir, makanan kekinian dalam penelitian ini adalah makanan dan minuman yg sedng hits dikalangan mahasiswa seperti kopi kekinian (janji jiwa, kopi kenangan dsb), boba (chatime, xing fu tang, kokumi dsb), brownies lumer, banana nugget, dessert box, mentai, corndog. (4) Responden memiliki salah satu $e$-wallet (OVO, DANA, Gopay, LinkAja atau ShopeePay).

Penelitian ini menggunakan variabel bebas dan variabel terikat. Variabel bebas $(\mathrm{X})$ dalam penelitian ini adalah gaya hidup konsumtif (X1) dan Promosi Penjualan (X2), sedangkan variabel terikat (Y) penelitian ini yaitu pembelian impulsif $(\mathrm{Y})$.

Ukuran sampel yang digunakan sebanyak 110 yaitu 100 sampel ditambah 10 sampel untuk angket yang cacat. Teknik pengumpulan data responden, dilakukan menggunakan metode snowball sampling dengan cara menghubungi responden kemudian mengecek apakah responden sesuai dengan karakteristik, jika sesuai responden akan diminta untuk mengisi angket secara online melalui google form setelah itu responden diminta untuk merekomendasikan rekan atau teman yang sesuai dengan karakteristik di atas. Angket penelitian diuji menggunakan uji validitas dan reliabilitas menggunakan sampel 30 responden menggunakan program SPSS 18.

\section{HASIL DAN PEMBAHASAN}

\section{Karakteristik Responden}

Karakteristik demografi berdasarkan jenis kelamin menunjukkan bahwa terdapat 110 responden, di mana $81(73,6 \%)$ responden berjenis kelamin perempuan dan 29 (26,4\%) berjenis kelamin laki-laki. Karakteristik demografi berdasarkan usia menunjukkan bahwa dari 110 responden terdapat 20 responden $(18,18 \%)$ dengan usia $\leq 20$ tahun, dan 90 responden $(81,82 \%)$ dengan usia $\geq 21$ tahun. Responden juga berasal dari berbagai daerah di Indonesia dengan 35 responden $(31,82 \%)$ berasal dari sekitar Surabaya yaitu Sidoarjo dan Gresik, dan 75 responden $(68,18 \%)$ berasal dari luar daerah Surabaya. Responden dari berbagai daerah tersebut menempuh pendidikan di perguruan tinggi yang berada di Surabaya yang didominasi oleh mahasiswa yang berasal dari Universitas Negeri Surabaya. Dengan hasil 33 responden $(30,0 \%)$ mahasiswa Unair, 57 responden $(51,8 \%)$ mahasiswa Unesa, 6 responden $(5,5 \%)$ mahasiswa ITS, 14 responden $(12,7 \%)$ dari perguruan tinggi lainnya di Surabaya. Karakteristik berdasarkan pengguna e-money menunjukkan bahwa dari 110 responden pengguna terbanyak adalah pengguna OVO yaitu 85 responden $(77,27 \%)$.

\section{Hasil Analisis Data}

Sebelum masuk ke uji analisis data, angket yang disebarkan harus diuji terlebih dahulu apakah angket tersebut valid dan reliable untuk digunakan dalam penelitian. Hasil dari uji validitas, semua item pertanyaan di angket dinyatakan valid yangmana diketahui bahwa masing-masing item memiliki jumlah r-hitung > r-tabel yaitu 0,316. Uji reliabilitas penelitian ini dari variabel dependent yaitu pembelian impulsif dan variabel independent yaitu gaya hidup konsumtif dan promosi penjualan masing-masing lebih besar dibandingkan nilai minimal Cronbach Alpha sebesar 0,60. Sehingga angket dapat dinyatakan reliabel untuk digunakan.

Sebelum menganalisis data menggunakan regresi linear berganda data diuji terlebih dahulu dengan uji asumsi klasik yaitu uji normalitas, uji heterokedastisitas, uji multikolinearitas. Hasil yang diperoleh nilai signifikansi Asymp. Sig. (2-tailed) sebesar 0,625 lebih besar dari 0,05. Maka sesuai dasar pengambilan keputusan dalam uji normalitas data tersebut berdistribusi normal. Dengan demikian asumsi atau persyaratan normalitas dalam model regresi sudah terpenuhi. 
Uji multikolinearitas nilai tolerance dari variabel gaya hidup konsumtif yaitu $0,885 \geq 0,01$. Dan nilai tolerance dari variabel promosi penjualan yaitu $0,885 \geq 0,01$. Dengan hasil tersebut, diketahui bahwa tidak terjadi multikolinearitas antar variabel independen. Begitu juga dengan nilai VIF dari masingmasing variabel independen, untuk nilai VIF dari variabel gaya hidup konsumtif yaitu $1,130 \leq 10$. Dan nilai VIF dari variabel promosi penjualan yaitu $1,130 \leq 10$. Artinya tidak terjadi multikolonieritas antar variabel independent. Dari hasil tersebut didapatkan hasil bahwa dalam penelitian ini tidak memiliki korelasi yang kuat antar variabel independen, sehingga model regresi ini dapat ditoleransi.

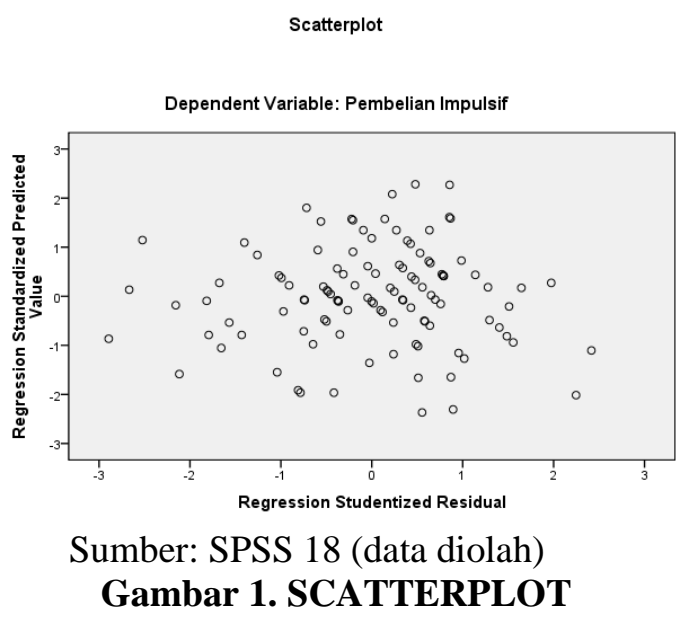

Gambar 1 menunjukkan bahwa titik menyebat dan tidak membentuk pola sehingga tidak terjadi heterokedastisitas dalam penelitian ini. Semua data telah lulus uji asumsi klasik sehingga dapat dilakukan uji analisis data. Hasil dari regresi linear berganda dapat dilihat dalam tabel 1. Berdasarkan tabel 1, dapat diperoleh model persamaan regresi linear berganda (1).

$\mathrm{Y}=5.717+0.352 \mathrm{X} 1+0.019 \mathrm{X} 2$

Keterangan:

$\mathrm{Y} \quad=$ Pembelian Impulsif

a $\quad$ Konstanta

$\mathrm{X} 1=$ Gaya Hidup Konsumtif

$\mathrm{X} 2=$ Promosi Penjualan

Tabel 1.

HASIL ANALISIS REGRESI LINEAR BERGANDA

\begin{tabular}{ccccc}
\hline Variabel & Unstandardized Coefficients $(B)$ Standardized Coefficients $($ Beta) & t & Sig. \\
\hline (Constant) & 5.717 & .478 & 2.933 & .004 \\
X1 & .352 & .030 & 5.331 & .000 \\
X2 & .019 & .340 & .735 \\
\hline
\end{tabular}

Sumber: SPSS 18 (data diolah)

Nilai konstanta 5.717 dapat diartikan bahwa apabila gaya hidup konsumtif (X1) dan promosi penjualan (X2) sama dengan nol (0) maka besarnya pembelian impulsif adalah 5.717. Dapat diketahui bahwa mahasiswa urban tetap melakukan pembelian impulsif (Y) terhadap makanan kekinian meskipun mahasiswa urban tidak memiliki gaya hidup konsumtif (X1) maupun ketika outlet makanan kekinian tidak melakukan promosi penjualan (X2).

Nilai koefisien variabel gaya hidup konsumtif (X1) sebesar 0.352 , artinya jika variabel gaya hidup konsumtif (X1) ditingkatkan dan variabel lainnya tetap maka keputusan melakukan pembelian impulsif 
Tamara Virsa Putri \& Sri Setyo Iriani. Pengaruh Gaya Hidup Konsumtif dan Promosi Penjualan Terhadap Pembelian Impulsif Makanan Kekinian Mahasiswa Urban Surabaya

(Y) juga akan meningkat sebesar 0.352 kali. Dapat diketahui bahwa apabila gaya hidup konsumtif (X1) mahasiswa urban terhadap makanan kekinian tinggi maka semakin yakin pula mahasiswa urban tersebut untuk melakukan pembelian impulsif (Y).

Nilai koefisien variabel promosi penjualan (X2) sebesar 0.019 , artinya apabila variabel promosi penjualan (X2) ditingkatkan maka akan mengakibatkan peningkatan pembelian impulsif (Y) sebesar 0,019 kali. Dapat diketahui bahwa jika semakin banyak promosi penjualan (X2) yang dilakukan di outlet makanan kekinian semakin banyak pula pembelian impulsif (Y) yang dilakukan mahasiswa urban.

Pengujian hipotesis pertama dilakukan menggunakan uji $\mathrm{F}$ dengan hasil pada Tabel 2. Hasil di atas menunjukkan nilai signifikansi $<0,05$ yang mana dapat diartikan bahwa model ini layak untuk digunakan, dengan nilai $\mathrm{R}$ (korelasi) dan $\mathrm{R}^{2}$ (Adjusted $R$ Square) pada Tabel 3.

Tabel 2.

NILAI UJI F

\begin{tabular}{lcc}
\hline \multicolumn{1}{c}{ Model } & F & Sig \\
\hline Regresi & 16.816 & $.000^{\mathrm{a}}$ \\
\hline Sumber: SPSS 18 (data diolah) &
\end{tabular}

Tabel 3.

NILAI ADJUSTED R SQUARE

\begin{tabular}{cccc}
\hline Model & R & R Square & Adjusted R Square \\
\hline 1 & .489 & .239 & .225 \\
\hline
\end{tabular}

Sumber: SPSS 18 (data diolah)

Berdasarkan tabel 3, dapat diketahui bahwa besarnya konstribusi variabel independent gaya hidup konsumtif (X1) dan promosi penjualan (X2) terhadap variabel dependent pembelian impulsif (Y). Nilai Adjusted R Square sebesar $0.225=22,5 \%$. Nilai tersebut menunjukkan bahwa gaya hidup konsumtif (X1) dan promosi penjualan (X2) terhadap variabel terikat pembelian impulsif sebesar 0.225 atau $22,5 \%$. Sedangkan sisanya $77,5 \%$ dipengaruhi oleh variabel di luar variabel yang digunakan dalam penelitian ini.

Pengujian hipotesis selanjutnya menggunakan uji t (uji parsial). Hasil uji t dapat dilihat pada tabel 1 di atas yang menujukkan nilai t hitung untuk variabel gaya hidup konsumtif (X1) adalah sebesar 5.331 dan didukung dengan nilai signifikan sebesar 0,000 yang lebih kecil dari 0,05 atau 5\%, maka $\mathrm{H}_{0}$ ditolak dan H1 diterima. Sehingga dapat dikatakan bahwa terdapat pengaruh positif antara gaya hidup konsumtif terhadap pembelian impulsif. Sedangkan untuk variabel promosi penjualan (X2) adalah sebesar 0.340 dan didukung dengan nilai signifikan sebesar 0,735 yang lebih besar dari 0,05 atau 5\%, maka $\mathrm{H}_{0}$ diterima dan $\mathrm{H} 1$ ditolak. Sehingga dapat dikatakan bahwa tidak terdapat pengaruh positif antara promosi penjualan terhadap pembelian impulsif mahasiswa urban Surabaya.

\section{Pengaruh Gaya Hidup Konsumtif terhadap Pembelian Impulsif}

Hasil dari penelitian ini bahwa terdapat pengaruh signifikan secara parsial antara gaya hidup konsumtif terhadap pembelian impulsif mahasiswa terhadap makanan kekinian. Arah hubungan dari pengaruh variabel gaya hidup terhadap pembelian impulsif ini pun adalah positif yang mana menunjukkan hubungan yang searah, yang berarti semakin konsumtif mahasiswa urban Surabaya semakin tinggi pembelian impulsif yang mereka lakukan.

Penelitian ini mendukung penelitian sebelumnya dari Nato (2018) yang menyatakan bahwa gaya hidup berpengaruh signifikan terhadap pembelian impulsif; Pramudi (2015) yang menjelaskan bahwa gaya hidup konsumtif merupakan salah satu faktor yang mendukung pembelian impulsif; Ahmed et al. (2015) yang mendapatkan hasil bahwa gaya hidup mempengaruhi pembelian impulsif. 
Rata-rata tertinggi jawaban responden tertuju pada indikator mencoba lebih dari dua produk sejenis. Artinya, banyak mahasiswa urban Surabaya yang suka menghabiskan uangnya dengan membeli satu produk dengan merek yang berbeda. Sesuai dengan teori yang dikemukakan oleh Anggarsari dalam Sumartono (2002:45) yaitu membeli barang yang kurang atau tidak diperhitungkan sehingga sifatnya berlebihan. Gaya hidup konsumtif yang mendorong mahasiwa urban Surabaya dalam penelitian ini adalah kecenderungan mahasiswa urban Surabaya untuk mengalokasikan uangnya pada makanan kekinian yang dilakukan secara berlebihan dengan menuruti tren serta gengsi agar tidak ketinggalan zaman.

Jika dikaitkan dengan karakteristik responden dalam penelitian ini, konsumen konsumtif yang melakukan pembelian impulsif mayoritas adalah mahasiswi urban Surabaya yang menempuh pendidikan di Unesa dengan rentang usia 18-24 tahun. Selain itu mahasiswa urban mayoritas berasal dari luar daerah Surabaya (luar Surabaya, Sidoarjo dan Gresik).

Didapatkan hasil bahwa gaya hidup konsumtif berpengaruh sigifikan terhadap pembelian impulsif. Yang artinya, bahwa mahasiswa urban melakukan pembelian impulsif terhadap makanan kekinian ini karena mahasiswa urban memiliki gaya hidup konsumtif atau dapat dikatakan bahwa gaya hidup mahasiswa urban ini mendorong mereka untuk melakukan pembelian impulsif.

\section{Pengaruh Promosi Penjualan terhadap Pembelian Impulsif}

Hasil dari penelitian ini bahwa tidak terdapat pengaruh signifikan antara promosi penjualan terhadap pembelian impulsif mahasiswa terhadap makanan kekinian. Penelitian ini tidak sejalan dengan penelitian yang dilakukan oleh Haq (2013); Amara \& Kchaou, (2014) dengan hasil bahwa promosi berpengaruh terhadap pembelian impulsif; Wahyudi, (2017) mendapatkan hasil bahwa pemberian diskon berpengaruh terhadap pembelian impulsif dan merupakan sumber kegiatan promosi bagi perusahaan; Kwan (2016) yang memperoleh hasil bahwa promosi penjualan berpengaruh terhadap pembelian impulsif. Tetapi penelitian ini sejalan dengan penelitian yang dilakukan oleh Waani \& Tumbuan (2015) yang mendapatkan hasil bahwa diskon harga tidak berpengaruh terhadap pembelian impulsif.

Rata-rata tertinggi jawaban responden terdapat pada indikator besaran diskon dengan item pernyataan "saya lebih memilih membeli makanan kekinian yang menawarkan diskon lebih besar." yang hasil nilainya masuk dalam kategori sangat setuju. Artinya mahasiswa urban Surabaya melihat besarnya diskon sebagai faktor pendorong mereka untuk melakukan pembelian impulsif. Promosi yang mendorong mahasiswa urban Surabaya untuk melakukan pembelian impulsif adalah promosi yang langsung menargetkan pada pemotongan harga baik itu melalui diskon maupun cashback yang ditawarkan oleh outlet atau e-money yang bekerja sama dengan outlet makanan kekinian.

Tetapi dalam menentukan pembelian pada makanan kekinian mahasiswa urban memiliki sifat penasaran yang tinggi, para mahasiswa urban tertarik pada makanan yang belum pernah mereka coba sebelumnya di kota asal mereka. Saat pertama membeli mereka akan meminta pendapat kepada teman atau lingkungan mereka yang mengetahui tentang tren makanan kekinian sehingga mereka tidak terlalu memperhatikan tentang promosi penjualan. Mahasiswa urban terus mencari makanan yang baru dan berbeda secara terus-menerus. Gaya hidup konsumtif mahasiswa urban yang suka membandingkan merek satu dengan merek yang lainnya yang membuat mereka tidak terfokus pada promosi yang dilakukan oleh outlet-outlet makanan kekinian tersebut.

Dari pembahasan tersebut diperoleh hasil bahwa promosi penjualan tidak berpengaruh signifikan terhadap pembelian impulsif. Yang artinya, bahwa mahasiswa urban Surabaya memiliki faktor pendorong lain dalam mempengaruhi keputusan untuk melakukan pembelian impulsif. 
Tamara Virsa Putri \& Sri Setyo Iriani. Pengaruh Gaya Hidup Konsumtif dan Promosi Penjualan Terhadap Pembelian Impulsif Makanan Kekinian Mahasiswa Urban Surabaya

\section{KESIMPULAN}

Pembelian impulsif terhadap makanan kekinian oleh mahasiswa urban di Surabaya dipengaruhi oleh gaya hidup konsumtif. Berdasarkan hasil analisis data yang telah dilakukan dan pembahasan yang telah dijabarkan dapat ditarik kesimpulan gaya hidup konsumtif (X1) berpengaruh terhadap pembelian impulsif terhadap makanan kekinian di Surabaya. Selain itu terdapat variabel promosi penjualan (X2) yang dalam penelitian ini tidak memiliki pengaruh yang signifikan terhadap pembelian impulsif.

Penelitian selanjutnya disarankan agar memperhitungkan jenis promosi lain yang terdapat dalam promosi penjualan yang dapat menstimuli mahasiswa urban untuk melakukan pembelian impulsif yaitu bonus pack, point of purchase display dan loyalty program, karena dalam penelitian ini hanya mengambil dua jenis promosi penjualan yaitu diskon dan cashback. Dalam penelitian ini angket yang disebarkan terbatas pada angket online sehingga data yang didapatkan kurang mendalam, kepada penelitian selanjutnya diharapkan menambahkan jenis instrumen penelitian seperti angket offline dan pengamatan lapangan. Makanan kekinian dalam penelitian ini tidak di cluster berdasarkan jenis minuman atau makanan, serta tidak membatasi tempat outlet yang diteliti sehingga pada penelitian selanjutnya diharapkan untuk menambahkan cluster serta tempat outlet lebih spesifik misalnya difokuskan pada satu jenis makanan di outlet makanan tertentu. Disarankan juga kepada penelitian selanjutnya untuk menambah literatur agar pembahasan lebih detail dan mendalam sehingga dapat bermanfaat untuk pemilik outlet makanan kekinian dalam menentukan strategi pemasaran, karena dalam penelitian ini literatur yang digunakan sangat terbatas dan kurang langsung mengimplikasi pada objek yang diteliti.

\section{DAFTAR PUSTAKA}

Ahmed, D. R. R., Soomro, H. A., Ali, Kashif, \& Ali, Wajid. (2015). Influence of Lifestyle and Cultural Values on Impulse Buying Behavior. SSRN Electronic Journal, (September). https://doi.org/10.2139/ssrn.2656033

Amara, R. Ben, \& Kchaou, A. S. (2014). The Role of Sales Promotion in inducing Impulse Purchases. $\begin{array}{lllll}\text { International Journal of Management } & \text { Excellence, } 3(1),\end{array}$ https://doi.org/10.17722/ijme.v3i1.144

BPS. (2019). Kota Surabaya Dalam Angka 2019. Diakses pada 3 Februari 2020, dikutip dari https://surabayakota.bps.go.id/publication/2019/08/16/000b29e29305774cd1ce8bdf/kotasurabaya-dalam-angka-2019.html.

F.Engel, J., D.Blackwell, R., \& W.Miniard, P. (2002). Perilaku Konsumen. Tangerang: Binarupa Aksara.

Gunawan Kwan, O. (2016). Pengaruh Sales Promotion Dan Store Atmosphere Terhadap Impulse Buying Dengan Positive Emotion Sebagai Variabel Intervening Pada Planet Sports Tunjungan Plaza Surabaya. Jurnal Manajemen Pemasaran, 10(1), 27-34. https://doi.org/10.9744/pemasaran.10.1.27-34

Haq, A. Al. (2013). Pembelian Secara Impulse Buying Wanita Bekerja Pada Matahari Department Store Plaza. Jurnal Aplikasi Bisnis, 89-109.

KBBI. (2019). Arti Kata Urbanisasi. Diakses pada 3 Februari 2020, dikutip dari https://kbbi.web.id/urbanisasi.

Kompasiana.com. (2019). Urbanisasi Justru Sebabkan Pengangguran di Surabaya Halaman all Kompasiana.com. Diakses pada 1 Februari 2020, dikutip dari Kompasiana.com website: https://www.kompasiana.com/risvisurya/5ce02ec86b07c5102b3103ef/urbanisasi-justrusebabkan-pengangguran-di-surabaya?page $=$ all 
Kotler, P., \& Keller, K. L. (2009). Manajemen Pemasaran jilid 1 \& jilid 2. Jakarta: Erlangga.

Lupiyoadi, R. (2013). Manajemen Pemasaran Jasa (Edisi Keti). Jakarta: Salemba Empat.

Malhotra, N. K., \& Birks, D. F. (2007). Marketing Research. Harlow, England: Prantice Hall, inc.

Mowen, C., \& Minor, J. M. (2001). Perilaku Konsumen. Jakarta: Erlangga.

Nagadeepa, C., Tamil Selvi, J., \& Pushpa, A. (2015). Impact of Sale Promotion Techniques on Consumers' Impulse Buyıng Behaviour towards Apparels at Bangalore. Asian Journal of Management Sciences \& Education, 4(1), 116-124.

Nato, D. N. S. (2018). Pengaruh Gaya Hidup Terhadap Kecenderungan Impulse buying (Studi Kasus Pada Mahasiswa di Lima Universitas di Yogyakarta). Skripsi. Fakultas Ekonomi Universitas Sanata Dharma.

Novitasani, L., \& Handoyo, P. (2014). Perubahan Gaya Hidup Konsumtif pada Mahasiswa Urban di UNESA. Paradigma, 02(chapt 1), 7.

Nurmasarie, R. (2013). Pengaruh Promosi Penjualan Dan Penjualan Perseorangan Terhadap Keputusan Belanja Tidak Terencana. Jurnal Ilmu Manajemen, 1(2), 531.

Pradana, M. F. (2013). Gaya hidup konsumtif pada mahasiswa. Skripsi. Fakultas Psikologi Universitas Muhamadiyah Malang.

Pramudi, R. Y. (2015). Pengaruh Gaya Hidup Konsumtif Dan Kelompok Referensi Terhadap Keputusan Pembelian Kosmetik Lokal. Jurnal Riset Ekonomi Dan Manajemen, 15(2), 280. https://doi.org/10.17970/jrem.15.150206.id

Ristekdikti. (2019). Jumlah Mahasiswa Jawa Timur 2019. Diakses pada 13 Januari 2020, dikutip dari https://forlap.ristekdikti.go.id/perguruantinggi/detail/MEEyNDI0QkItQjRCNy00NTQyLUEwN UUtODUxMzJGRDNCMjc2\&ved=2ahUKEwjcl5Hhp4bqAhUBT30KHaH5C_QQFjAAegQIA RAB\&usg=AOvVaw04INs0ozB5SUX2S3JaNxbe\&cshid=1592309707039..

Sari, A. E. (2014). Analisis Faktor Yang Mempengaruhi Pembelian Spontan. Analisis Faktor Yang Mempengaruhi Pembelian Spontan, 13(1), 55-73. https://doi.org/10.14710/jspi.v13i1.55-73

Slickdeals.net. (2018). Slickdeals Shares New Survey Data Showing Americans Spend \$324,000 On Impulse Buys In Their Lifetime. Diakses pada 1 Februari 2020, dikutip dari Slickdeals.net website: https://www.prnewswire.com/news-releases/slickdeals-shares-new-survey-datashowing-americans-spend-324000-on-impulse-buys-in-their-lifetime-300601768.html

Sumartono. (2002). Terperangkap dalam Iklan (Meneropong Imbas Pesan Iklan Televisi). Bandung: Alfabeta.

Sumarwan, U. (2015). Pemasaran Strategik: Prespektif Perilaku Konsumen, dan Marketing Plan. Jakarta: PT.Ghalia Indonesia.

Tjiptono, F., \& Chandra, G. (2012). Pemasaran Strategik. Yogyakarta: CV. Andi Offset.

Utami, C. W. (2018). Manajemen Ritel: Strategi dan Implementasi Operasional Bisnis Ritel Modern di Indonesia. Jakarta : Salemba Empat.

Voguebusiness.com. (2020). Gen Z is reinventing social media marketing|Vogue Business. Diakses pada 1 Maret 2020, dikutip dari Voguebusiness.com website: 
Tamara Virsa Putri \& Sri Setyo Iriani. Pengaruh Gaya Hidup Konsumtif dan Promosi Penjualan Terhadap Pembelian Impulsif Makanan Kekinian Mahasiswa Urban Surabaya

https://www.voguebusiness.com/consumers/gen-z-reinventing-social-media-marketing-tiktokyoutube-instagram-louis-vuitton

Waani, R. C. T., \& Alfa Tumbuan, W. J. F. (2015). the Influence of Price Discount, Bonus Pack, and in-Store Display on Impulse Buying Decision in Hypermart Kairagi Manado. F.A. Tumbuan. The Influence of Price... Jurnal EMBA, 33(4213), 420-428.

Wahidah, R., Imran, \& Bahari, Y. (2018). Dampak gaya hidup konsumtif pada kehidupan sosial dan prestasi mahasiswa. Jurnal untan, (21), 1-8.

Wahyudi, S. (2017). Pengaruh Price Discount Terhadap Impulse Buying. Universitas Nusantara PGRI Kediri, 01(2), 1-7.

Xu, Y., \& Huang, J. S. (2014). Effects of price discounts and bonus packs on online impulse buying. Social Behavior and Personality, 42(8), 1293-1302. https://doi.org/10.2224/sbp.2014.42.8.1293 